\title{
The "Life" in the Living Law: Law, Emotion and Landscape
}

\author{
Harison Citrawan \\ h.citrawan@hotmail.com
}

\begin{abstract}
This article explores the concept of 'living law' from a spatio-temporal and emotional perspective. Understood as a dynamic and interactive process, living law shapes and reproduces the concepts of law, emotion, and landscape. Based on the semantic findings in decency-related court decisions, this article argues that sensing the living law is to be understood as seeing the physical legal landscape, believing emotional common sense, and anticipating guided by communitarian atmosphere. The daily (legal) experiences captured in case-law are, essentially, assemblages of various meanings and spaces tied up homogeneously in an ideologically manner. Through this examination, living law appears increasingly complex, unstable, and non-linear, especially in terms of its performativity. Law has the potential not only to facilitate social transformation but can negatively impact vulnerable groups.
\end{abstract}

Keywords: emotion, landscape, living law, performativity

Copyright $\odot 2021$ by Author(s)

This work is licensed under a Creative Commons Attribution-ShareAlike 4.0 International License. All writings published in this journal are personal views of the authors and do not represent the views of thisjournal and the author's affiliated institutions.

\section{HOW TO CITE:}

Citrawan, Harison. "The "Life" in the Living Law: Law, Emotion and Landscape" (2021) 1:2 Contemporary Sociological Issues 124-144.

Submitted :December 14, 2021

Revised : June 22, 2020
Accepted

Publish
: July 25, 2021

: August 31, 2021 


\section{INTRODUCTION}

The law that lives in society has been widely reviewed by legal scholars. Dominated by the reviews of sociologists and anthropologists of law, the so-called living law carries a very diverse lexicon, spectrum, and context among thinkers. Eugene Ehrlich, one of the founders of the sociology of law ${ }^{1}$, has traced the concept of living law. As part of his rejection of restrictive legal analyses that only pay attention to the state, regulations, procedures, and courts, Ehrlich offers the concept of 'living law' as an alternative, defined as:

the law that dominates life itself even though it has not been posited in legal propositions. The source of our knowledge of this law is, first the modern legal document, secondly, direct observation of life, of commerce, of customs and usages and of all associations, not only those that the law has recognized but also those that it has overlooked and passed by, indeed even those that it has disapproved. $^{2}$

In Indonesia, the dynamics of understanding and applying living laws show various characteristics over time (Van Vollenhoven, 1918, 1932; von Benda-Beckmann \& von Benda-Beckmann, 2009). As a former Dutch colony, van Vollenhoven's thoughts, along with the Rijksuniversiteit Leiden's legacy, have greatly influenced the sustainability and translation of the laws that live in Indonesian society. ${ }^{3}$ Through tracing historical trajectories, von Beckman explains that there has been "a turn from an analytical instrument towards a legal (folk) concept incorporated into the official legal and judicial machinery of the state, and to some extent as a weapon to invalidate 'the real' living law." Lev, as an Indonesianist in the field of legal anthropology, explained that the colonial politics "served to transform adat increasingly into the conservative legitimating symbol of local authorities ... against Islamic challenges." 5 The dynamics of living law within the legal system has continued into the post-reform era. By taking the larger politicaleconomic agenda into consideration, Buana revealed that the commonality of living adat law "may lead to a purification, which would eventually create exclusivism and a patronclient relationship."

\footnotetext{
${ }^{1}$ Reza Banakar, Normativity in Legal Sociology: Methodological Reflections on Law and Regulation in Late Modernity (London: Springer, 2015); Mathieu Deflem, Sociology of law: Visions of a scholarly tradition (Cambridge: Cambridge University Press, 2008).

${ }^{2}$ Eugen Ehrlich, Fundamental Principles of the Sociology of Law (London, New York: Routledge, 2002) at 493.

${ }^{3}$ M Yahdi Salampessy, "Book Review The Leiden Legacy: Concepts of Law in Indonesia" (2014) 4:3 Indones Law Rev 385-388.

${ }^{4}$ Franz von Benda-Beckmann \& Keebet von Benda-Beckmann, "The Social Life of Living Law in Indonesia" in Marc Hertogh, ed, Living Law Reconsidering Eugen Ehrlich (Oxford, Portland: Hart Publishing, 2009) 177 at 197.

${ }^{5}$ Daniel S Lev, "Colonial Law and the Genesis of the Indonesian State" (1985) 40 Indonesia 57-74 at 66.

${ }^{6}$ Mirza Satria Buana, "Living adat Law, Indigenous Peoples and the State Law: A Complex Map of Legal Pluralism in Indonesia" (2016) 1:3 Int J Indones Stud 104-119 at 116.
} 
In its development, studies on living law also consider the spatio-temporal aspect of society, which has been widely discussed in the interdisciplinary science of legal geography. ${ }^{7}$ Studies in legal geography, however, are still relatively rare in Indonesia. Hexagraha's review on Spatial Planning Laws argues that the lack of meaningful participation has created discriminatory urban planning and development. ${ }^{8}$ Immersed by the idea of spatial justice, an analysis of the Ciliwung River normalization administrative suit explains that the law fails to accommodate reparation for the vulnerable groups affected by discriminatory policies. ${ }^{9}$ Nalle goes further to propose the idea of a 'lawscape' as part of legal analysis in understanding spatial justice in urban planning. ${ }^{10}$ While these two articles have paved the way for discussing spatial justice in Indonesia, they focus on the critique of spatial planning as a technocratic document, which neglecting the everyday life of law. ${ }^{11}$ In this sense, both Hexagraha and Nalle refer to the law as a discourse. Viewed differently, when referring to the tautological concept of law and space, law can be considered performative. In this sense, it can be useful to understand and represent law as living concept. As an attempt to sensitize legal pluralism into space and temporality, von Benda-Beckman and von Benda-Beckman argue that the categorical legal schemes in this concept produce multi-normative spaces, in which "the processes that create, sustain, and dissolve places all have their own specific temporality that is shaped by a complex interplay of physical, social, and legal factors." 12

This article argues that viewing living law through the lens of performativity invites an emotional component to influence the law as a daily experience. ${ }^{13}$ Understood as a dynamic interplay between processes, living law carries an inherently collective emotional experience. However, the spatio-temporal elements of these collective emotions have not been explored in much detail in the Indonesian context. This article aims to explain law in terms of three aspects: law, emotion, and landscape. Through this examination, the concept of living law becomes increasingly complex. On the one hand,

\footnotetext{
${ }^{7}$ Irus Braverman et al, "Expanding the Spaces of Law" in Expand Spaces Law A Timely Leg Geogr (Stanford, CA: Stanford University Press, 2014) 1; David Delaney, "Legal geography I: Constitutivities, complexities, and contingencies" (2015) 39:1 Prog Hum Geogr 96-102.

${ }^{8}$ Shafira Anindia Alif Hexagraha, "Trajektori ko-produksi kota di Indonesia: Telaah geografi kritis" (2018) 5:1 J Huk Lingkung 88-116.

${ }^{9}$ Shafira Anindia Alif Hexagraha \& Savitri Nur Setyorini, "Tinjauan terhadap Konsep Keadilan Spasial dan Partisipasi Masyarakat dalam Perencanaan dan Pengendalian Pemanfaatan Ruang pada Program Normalisasi Ciliwung di Provinsi DKI Jakarta" (2019) 49:2 J Huk Pembang 349-375.

${ }^{10}$ Victor Imanuel Nalle, "Pendekatan Geografi Hukum Kritis dalam Kajian Hukum Tata Ruang Indonesia: Sebuah Wacana Filsafat Hukum dan Interdisiplin" (2021) 37:1 Justitia Pax J Huk 61-83.

${ }^{11}$ Hexagraha, supra note 8.

${ }^{12}$ Franz von Benda-Beckmann \& Keebet von Benda-Beckmann, "Places that come and go: A legal anthropological perspective on the temporalities of space in plural legal orders" in Irus Braverman et al, eds, Expand Spaces Law A Timely Leg Geogr (Stanford, CA: Stanford University Press, 2014) 30 at 36.

${ }^{13}$ Martha M Umphrey, "Law in Drag: Trials and Legal Performativity" (2012) 21:2 Columbia J Gend Law 114-129; Judith Butler, "Performativity, precarity and sexual politics" (2009) 4:3 AIBR Rev Antropol Iberoam.
} 
its performativity can negatively impact vulnerable groups. On the other hand, it has the potential to open up space for social transformation facilitated by law.

In exploring the relationship between legal performativity, emotion, and landscape, this article analyses several Indonesian criminal court decisions that contain the elements of decency. According to R. Soesilo, "the destructive nature of the decency of these acts is sometimes very dependent on public opinion at that time and place." ${ }^{14}$ In addition, the meaning of decency is narrowing, exclusively questioning the social aspect of sexuality. ${ }^{15}$ By analyzing the pluralistic performativity of law in these cases, this article concludes by discussing the underlying ideological dimensions of law that unconscientiously materialize in the experience of living law.

\section{THE 'LIFE' IN QUEST: PEOPLE-SPACE-EMOTION}

Understanding law through the lens of everyday life derives its theoretical basis from legal pluralism. This framework shifts a static, formalist, and positivist perspective towards an understanding of law that is "more open, plural, and based on social facts, more textual, and more sensitive to power-law relation." ${ }^{16}$ Margaret Davies arrives at the state of legal pluralism as conceptual dynamism, resulting from the interrelations between legal paradigm shifts, the crisis of subjectivity that emphasizes posthuman existence, the balanced relationship between matter and meaning, and the irreducibility of theoretical objects into one singular form. ${ }^{17}$ Building upon this cognizance of the plurality of law, the following section stretches the conceptual framework surrounding the quests of landscape, emotion, and atmosphere in an attempt to re-frame law as a living concept.

\section{A. Landscape/Legal}

In the field of critical geography, the idea of legal interplay within space has been widely discussed. Several key features are useful to highlight. Moving beyond the question of what and how the legal and the spatial are related, Delaney introduces the concept of nomosphere to explore how they happen. This concept is defined as "a way of thinking about the complex, shifting, and always interpretable blendings of words and worlds, in which our lives are always embedded and unfolding." ${ }^{18}$ Bennett and Layard suggest that legal scholars and geographers should work hand-in-hand as spatial detectives to "search out the presence and absence of spatialities in legal practice and of

\footnotetext{
${ }^{14}$ R Soesilo, Kitab Undang-Undang Hukum Pidana (KUHP) serta Komentar-Komentarnya Lengkap Pasal Demi Pasal (Bogor: Politeia, 2013).

${ }^{15}$ Hendri Yulius, "Double standards: The defining of homosexuality as pornographic in Indonesia", Jakarta Post (21 October 2016), online: ‘https://www.thejakartapost.com/academia/2016/10/21/double-standardsthe-defining-of-homosexuality-as-pornographic-in-indonesia.html.>.

${ }^{16}$ Margaret Davies, Law Unlimited: Materialism, Pluralism, and Legal Theory (New York: Routledge, 2017) at 1.

${ }^{17}$ Davies, supra note 16.

${ }^{18}$ David Delaney, The Spatial, the Legal and the Pragmatics of World-Making: Nomospheric Investigation (New York: Routledge, 2010) at 26.
} 
law's traces and effects embedded within places." ${ }^{19}$ Informed by the everyday formation perspective, Azuela and Reyes propose that the spatial-turn of law is reflected "... [i]n how certain spatial formations have been given meaning through legal practices [and] could illustrate the ways in which the law serves as a means to produce and reproduce an imaginary spatial cohesion in an urban space of conflicting values and expectations."20 Within the condition of legal pluralism "multiple legal constructions of space open up multiple arenas for the exercise of political authority, the localization of rights and obligations, as well as the creation of social relationships and institutions that are characterized by different degrees of abstraction, different temporalities and moral connotations." 21

Both law and geography are central cultural practices in the theorization of landscape. Delaney argues that: "[e]very landscape "item" - including embodied creatures - is the material referent of legal discourse . . . landscapes become the materialization of the legal as such." ${ }^{22}$ Legal landscapes are essentially a product, being simultaneously produced and reproduced; its "constitutive meanings are taken up by situated actors as instructions of a sort for how to navigate and engage them." ${ }^{23}$ While many studies focus seeing through or viewing legal landscapes, they can also refer to a complex set of customs, morals, and emotions. ${ }^{24}$ By considering law's affects and emotive qualities, the legal landscape is thus understood as being "formed in the interplay of the state's ideals, local particularities, customs, and conventions that are not necessarily written, but become visible in customary community practice or in the habitus of landscape." 25

\section{B. Landscape/Emotion}

The study of law and emotion poses a direct challenge against the notion that a clear distinction can be made between emotion and reason; it rejects the argument that the law has no passion (dispassionate law) ${ }^{26}$ Interdisciplinary nature such as science,

\footnotetext{
${ }^{19}$ Luke Bennett \& Antonia Layard, "Legal Geography: Becoming Spatial Detectives" (2015) 9:7 Geogr Compass 406-422 at 406.

${ }^{20}$ Antonio Azuela \& Rodrigo Meneses-Reyes, "The everyday formation of the urban space: Law and poverty in Mexico City" in Irus Braverman et al, eds, Expand Spaces Law A Timely Leg Geogr (Stanford, CA: Stanford University Press, 2015) 167 at 167.

${ }^{21}$ Franz von Benda-Beckmann, Keebet von Benda-Beckmann \& Anne Griffiths, "Space and legal pluralism: An introduction" in Franz von Benda-Beckmann, Keebet von Benda-Beckmann \& Anne Griffiths, eds, Spat law An Anthropol Geogr law Soc (Surrey: Ashgate, 2009) l at 4.

${ }^{22}$ David Delaney, "Seeing seeing seeing the legal landscape" in Nuala C Johnson, Richard H Schein \& Jamie Winders, eds, Wiley-Blackwell Companion to Cult Geogr (West Sussex: Wiley Blackwell, 2013) 238 at 242. ${ }^{23}$ Ibid at 243-244.

${ }^{24}$ Päivi Rannila \& Siiri Pyykkönen, "Public obscenity and the formation of emotional legal landscapes in Dries Verhoeven's Ceci n'est pas ...” (2020) 102:4 Geogr Ann Ser B, Hum Geogr 384-399; Kenneth R Olwig, The meanings of landscape: Essays on place, space, environment and justice (Oxon, New York: Routledge, 2019).

${ }^{25}$ Rannila \& Pyykkönen, supra note 24 at 389.

${ }^{26}$ Heather Conway \& John Stannard, "Contextualising Law and Emotion: Past Narratives and Future Directions" in Heather Conway \& John Stannard, eds, Emot Dyn Law Leg Discourse (Oxford and Portland, Oregon: Hart Publishing, 2016) l.
} 
culture, and social sciences, law and emotion are disciplines that examine behavioral realism into the world of law. ${ }^{27}$ A variety of legal and emotional examinations is a step towards challenging the traditional separation of emotion and reason. ${ }^{28}$ Amid the growing variety of multidimensional legal and emotional studies, Maroney proposes six typologies for these areas of study. The first is an emotion-centered approach that examines certain emotions - such as disgust, shame, or fear - and considers how they should be reflected in the law. ${ }^{29}$ The focus is on emotionally-driven phenomena - such as empathy, forgiveness, and remorse through forgiveness, focusing on "mental or behavioral processes in which emotion plays an important role, but is not itself an emotion. ${ }^{30}$ Second is emotion theory, which examinines a particular theory of emotion and incorporates law into it. ${ }^{31}$ Standing on the legal side as a driving force, various studies also focus on legal doctrine or theory of law, analyzing "how these areas of law mix or combine emotions. ${ }^{32}$ The legal actor approach is concerned with "individuals inhabiting the legal system [such as judges, jurors, and advocates] and explores how emotions influence and inform, or should influence or inform, the performance of the legal functions assigned to them." ${ }^{33}$

Analyses of the intersection between law and emotion can, in principle, pave the way for realizing a realistic and legitimate legal system. According to Grossi, "[u]sing law as a lens for understanding emotions provides an insight into emotions as a public rather than just a private phenomenon." ${ }^{34}$ Emotions can not only be found at the individualpersonal level but also in the institutional-group environment. ${ }^{35}$ Building upon the rationalist model of emotion and reasoning, Haidt exposes a social intuitionist model, which considers "the complex and dynamic ways that intuition, reasoning, and social influences interact to produce moral judgment." 36 By bringing emotion into a larger sphere, we can see "the propriety of emotional common sense in law" yielding "competing correct' versions of reality", ${ }^{37}$ which its expression "positively bristles with culturally specific, morally contested judgments - the very judgments on which the Constitution

\footnotetext{
${ }^{27}$ Terry A Maroney, "Lay conceptions of emotion in law" in Susan A Bandes et al, eds, Res Handb law Emot (Cheltenham, UK; Northampton, USA: Edward Elgar Publishing, 2021) 15.

${ }^{28}$ Maria Gendron, "The evolving neuroscience of emotion: challenges and opportunities for integration with the law" in Susan A Bandes et al, eds, Res Handb Law Emot (Cheltenham, UK; Northampton, USA: Edward Elgar Publishing, 2021) 27.

${ }^{29}$ Terry A Maroney, "Law and emotion: A proposed taxonomy of an emerging field" (2006) 30:2 Law Hum Behav $119-142$ at 125.

${ }^{30} \mathrm{Ibid}$ at 127.

${ }^{31}$ Ibid at 128; Dan M Kahan \& Martha C Nussbaum, "Two conceptions of emotion in criminal law" (1996) 96:2 Columbia Law Rev 269-374.

${ }^{32}$ Maroney, supra note 29 at 129.

${ }^{33} \mathrm{Ibid}$ at 131.

${ }^{34}$ Renata Grossi, "Understanding law and emotion" (2015) 7:1 Emot Rev 55-60 at 58.

${ }^{35}$ Susan A Bandes \& Jeremy A Blumenthal, "Emotion and the law" (2012) 8:May Annu Rev Law Soc Sci $161-181$ at 172.

${ }^{36}$ Jonathan Haidt, "The emotional dog and its rational tail: a social intuitionist approach to moral judgment" (2001) 108:4 Psychol Rev 814 at 1045.

${ }^{37}$ Maroney, supra note 27 at 20.
} 
is meant to remain agnostic, according to Roe and its progeny-and forces a false consensus on them." ${ }^{38}$

\section{Lawscape/Atmosphere}

Approaching the influence of affects, senses to the spatio-temporal aesthetics of law, Philippopulos-Mihalopoulos defines atmosphere as "the varying measures of normativity and space that appear simultaneously in the lawscape" and "the excess of affect that keeps bodies together." 39 It is "a force of attraction", generated in "shared urban skin, caressing, scenting, beating, biting spaces and bodies and holding them together . .."40 The atmosphere of the lawscape he argues, "focuses on the reciprocal invisibilisation of space and normativity." It is "the way varying degrees of normativity and space appear every time, thus managing to dissimulate the fact that space is fully given to law and law is fully given to spatiality." ${ }^{41}$ It is the engineering of the atmosphere of lawscape that dissimulates the landscape, or in Philippopulos-Mihalopoulos' city, to be "guided by preference, choice, opportunity, freedom." ${ }^{42}$ Central to his claim is dissimulation, on how to manipulate senses, emotion, meaning in the atmosphere.

Spatial justice can be defined as "the struggle between bodies to be in a specific space at a specific time." ${ }^{43}$ It is "in the middle of desiring bodies, of conative spaces, of lawscaping practices, of atmospheric enclosures." 44 In this sense, spatial justice brings to the fore the spatial positioning of corporeality of material bodies - a body understood not only isolated in an individual human, but "as an assemblage of various conditions and materialities." 45 These atmospheric elements of legal landscapes can bring out a diverse understanding of emotional common sense within the multinormativity of legal pluralism.

\section{SENSING THE DECENT}

This article now turns to public morality as one of the discourses pertaining to law that lives in society. Through Ehrlich's perspective on the plurality of binding norms in society, a discussion on decency (kesusilaan) would be conspicuous in revealing a novel understanding of the living law in Indonesia. Focusing on legal cases related to decency and homosexuality this article explores how the dynamics of law, landscape, and emotion work and evolve by shaping and reshaping each other. As a matter of legal norm, Article 281 of the Criminal Code is central. It stipulates:

\footnotetext{
${ }^{38} \mathrm{Ibid}$ at 23 .

${ }^{39}$ Andreas Philippopoulos-Mihalopoulos, "Atmospheres of law: Senses, affects, lawscapes” (2013) 7:1 Emot Sp Soc 35-44 at 39-41.

${ }^{40} \mathrm{Ibid}$ at 41.

${ }^{41}$ Ibid at 42.

${ }^{42}$ Ibid.

${ }^{43}$ Andreas Philippopoulos-Mihalopoulos, Spatial Justice: Body, Lawscape, Atmosphere (New York: Routledge, 2015) at 176.

${ }^{44} \mathrm{Ibid}$ at 187.

${ }^{45} \mathrm{Ibid}$ at 176.
} 
By a maximum imprisonment of two years and eight months or a maximum fine of three thousand rupiahs shall be punished: (1) any person who with deliberate intent publicly offends against decency; and (2) the person who with deliberate intent offends against decency whereby another person is present in spite of himself.

Several crimes are included within the ambit of decency, for example: child molestation, public obscenity, rape, adultery, and pornography. No existing laws explicitly prohibit homosexual activities. In the following sections, we may discern that decency perplexedly corresponds with the idea of living law as (A) predictive, (B) based on an emotional common sense; and (C) built upon the spirit of communitarianism that flattens the public and the private landscape.

\section{A. Seeing - A Predictive Landscape}

Sensing is about seeing. The first legal characteristic that shapes decency is the sense of seeing. In one case related to violation of decency at the Military Court, the Judges affirmed this pluralistic view, arguing that:

Violating decency in this offense is an act/action that violates politeness, courtesy, civility in the field of decency that must be related to sex and/or certain other body parts, which in general can cause feelings of shame, disgust or stimulate the lust of others, for example: touching a woman's breasts, touching a woman's genitals, kissing, exposing male/female genitalia;

Due to the various dimensions of decency according to customs (ethnic groups in Indonesia), the judex factie needs to consider the size of decency that applies according to the place and conditions in that place. (p. 23)

Decision No. 18-K/PMT-I/AD/XI/2019 of the Military Court refers to a similar argument, adding Andi Hamzah's opinion of the term de eerbaarheid schendt - the Dutch term for violating decency in Dutch. The Panel of Judges stated that the violation of decency was to be interpreted

... as causing sexual shame. This offense is a deliberate offense that violates the shame (schennis) of others who witness it. The Hoge Raad ruled on December 1, 1971, NJ1971,37: the act in question must be examined against public morals. The meaning of violating decency according to the Hoge Raad must be seen in the opinion that lives in the majority of the Dutch people (HR 19 November 1974 NJ 1975,133). The question is how can judges know the general opinion of the majority of the people? For the State of Indonesia, the solution is to use a sociological interpretation (an interpretation that is adapted to the circumstances of its people)... (p.35)

However, through a careful reading of these cases, it is unfortunate that the judges fail to sociologically further and explain the "interpretation that is adapted to the 
circumstances of its people." Instead, the judge expressed a rather moral intuition towards a series of emotional evidence, such as the way the gay defendant had sexual relations with his partner.

From the description above, it can be believed that the Defendant who had committed deviant sex with the Third Witness three times, first, the Third Witness sucked the Defendant's genitals until it was tense and reached climax/orgasm and then inserted it into the Third Witness' anus while imagine doing with the Defendant's girlfriend until the Defendant reaches a climax/orgasm, and released his sperm in the rectum/anus of the Third Witness, which is carried out in the Barracks, where the Barracks are occupied by more than 25 (twenty five) youth private soldiers, and in the bathrooms of the Youth Private Soldiers in where the bathroom is not a private bathroom but for many people, and is not locked, but only closed which even though it is done at midnight, but if someone wakes up and can directly see what the Defendant and Third Witness are doing, whether in the Barracks or in the bathroom, it can cause disgust or be stimulated/disturbed and cause lust or shame when seeing it. (p.26)

The same logic can be found in other crimes against decency under Article 281 (1) of the Criminal Code. In Decision No. 13-K/PM.II-09/AU/I/2020, the Panel of Judges did not contextualise decency in a particular space and time but relied on the perception or judgment of other people's disgust, lust, and shame. In the context of this provision, the Court is of the opinion that "[What] is meant by violating decency is an act that (violates) feelings of shame related to the lust of others." (p.21) Then, referring to the facts presented during the trial, the Panel of Judges notes that:

it is true that the family room of Third Witness' house is in the living room of Third Witness' parents... The place where the Defendant and Third Witness had deviant same-sex, anal sex, is an open place because at any time if someone enters, they can see the actions of the Defendant and Third Witness, so that people who see the act will be stimulated by their decency, and the living room is a public place is not a private place of a person and can cause lust or disgust or shame for those who see it. (p.23-24)

Upon examining this case law, the key characteristic in the interplay between decency and landscape is twofold. The common legal understanding is that decency is closely related to politeness, courtesy, and civility, coupled with the expression and performance of body and sex. This idea shapes and is shaped by the landscape within which it occurs. It can be an open or closed space, accessible or inaccessible to other people. It may or may not cause lust, disgust, and shame. Through a spatio-temporal lens, the boundary between public and private places is blurred and the temporal element is flattened by emotions toward homosexuals. These emotions are then reconfigured in terms of how the sexual orientation of minority groups can be expressed in certain spaces and the effects of this. The (il)legality of decency is therefore highly contingent on the lawscaping of lust and sexual desire. 


\section{B. Believing - Emotional Common Sense}

Sensing is about believing. The subsequent characteristic of living law is the belief that there is universal common sense. The proposition to integrate religious norms and institutions into living law has been contentious. In Indonesian legal discourse, there has been temptation to see Islamic religious norms as a living law in society. Intertwining with the politics of citizenship, especially during the authoritarian regime (1966-1998), religious norms significantly affect emotions in legal decision-making, particularly by inducing public morality and divinity in decency-related cases.

An important case to highlight is the Constitutional Review on decency crimes under the Criminal Code (Decision No. 46/PUU-XIV/2016). In this case, one of the plaintiff's requests is for the Constitutional Court to broaden the scope of Criminal Code to include homosexuality. It is important, however, to highlight the dissenting opinions by four Constitutional Justices, in which it reflects a moral intuition that considers homosexuality as despicable behavior that contrary to religious law and the constitution.

Historically, the inclusion of an objective element of "minors of the same sex" in the a quo article is clearly a 'victory' for homosexuals and some members of the Dutch Tweede Kamer who are indeed affirmative of the practice of homosexuality, even though the practice of homosexuality is clearly a sexual behavior which is intrinsic, inhumane, and universally reprehensible according to religious law and divine right as well as the legal values that live in society (living law) so that we are of the opinion that the word "adult," the phrase "not yet mature," and the phrase "which or should be presumed to be immature" in Article 292 of the Criminal Code which should be declared contrary to the 1945 Constitution and has no binding legal force.

$[\ldots]$

Thus, the 1945 Constitution must not allow everyone's absolute freedom to act solely according to their will, even more so in the event that the act clearly reduces, narrows, exceeds limits, and is contrary to religious values and divine light. Therefore, when the 1945 Constitution intersects with religious values, the 1945 Constitution as a divine constitution (Godly Constitution) must affirm its identity as a guarantor of freedom of religion and not freedom from religion so that all legal certainty in the form of legal norms that reducing, narrowing, exceeding limits, and even contradicting religious values and divine rays must be declared contrary to the 1945 Constitution and has no binding legal force.

In case No. 49-K/PM.II-09/AD/III/2020 The Panel of Judges concluded several facts of the trial: 
21. That it is true that with the incident that became this case where the Defendant had deviant sex/liked same-sex (LGBT) with the 3rd Witness, the Defendant is very sorry for the act and the Defendant will change so that in the future he will not do it again.

22. That it is true that deviant sex acts/relationships with the same sex are acts that violate the norms of law, religion, and decency, and are against God's nature, which should only be done with the opposite sex (male and female) who are bound by a legal marriage.

From these arguments, the Court declares that homosexuality is (1) a violation of legal norms, (2) a violation of religion and decency, and (3) contrary to God's nature regarding sexual relations that are only heterosexual and under legal marriage.

In the case of the criminal act of providing pornographic services involving homosexual activity, the Judge in Decision No. 572/Pid.Sus/2018/PN.JKT.PST stated that the punishment was heavier for the defendant for "violating decency and religious norms that can cause unrest in the community" (p.50). Although Article 4, Paragraph 2 of the Pornography Law does not require religious norms and morality, the opinion of the Panel of Judges is in line with the expert testimony presented at the trial. The expert, in this case, revealed that:

the scope of Law No. 4 of 2008 is to protect children and women, this law is more complex than the Criminal Code, there are spreading, distributing, and others related to pornography, images, body movements, and so on that have elements and are shown in public, in the Criminal Code itself if in Law no. 4 of 2008 is more complex [. . . - Whereas in Law no. 4 of 2008 does not provide a definition of same-sex relationship, but in Indonesia, based on Islamic teachings, same-sex relationships are prohibited, but in the law it is to protect women or men. (p.32) This case-law exerts that there is a belief that the living law bears the same weight with religious, divine norms, and that the legality of an act is produced through an assessment of whether it "reduces, narrows, exceeds limits, and is contrary to religious values and divine light." While the Judges have always separated these terms with commas, indicating that they are distinct concepts, legal interpretations appear to equate them, treating them as synonymous. Decency is calculated as emotional common sense derived from the traditional beliefs or religious teachings in the country. This equation promps deeper investigate into the interplay between emotion and public unrest.

\section{Anticipating - Communitarian Atmosphere}

Sensing is about anticipating. The next characteristic of decency is that it is built upon the spirit of communitarianism. In this sense, there is some kind of causal logic between violations of decency and public or social unrest. It is this spirit itself that engineers the process of the atmosphere of decency lawscape as it invisibles spatiality and normativity. The following cases demonstrate how affects and desires are guided and controlled by the ubiquity of atmosphere. 
In an Electronic Information and Technology Law case (Balikpapan District Court Decision No. 75/Pid.Sus/2019/PN Bpp.), we could discern the dissimulation of law and space through the materialization of digital landscape. In this case, the defendant, Arifin, was charged with committing a criminal act of "intentionally and without the right distributing and/or transmitting and/or making accessible electronic information and/or electronic documents containing subject that violates decency." This case began when the defendant Arifin asked for a Facebook account to be created by the name of Arifin Bpn by Arman, who then also created a Facebook group under the name 'Gay Massage Balikpapan City'. The defendant was then secured along with the Blued application found when the defendant sent a picture of their genitals to a friend under the name asRuLLLL. The Judge's legal argument was that the elements in Article 27 Paragraph (1), in conjunction with Article 45 Paragraph (1), of the 2008 Information and Electronic Transaction Law Republic of Indonesia Law had been fulfilled. First, the responsible subject clause, whereby the defendant was proven to be capable of, and able to be held accountable for, his actions. Second, the element of intentionality and arbitrariness in distributing and/or transmitting and/or making electronic information accessible. This was drawn when the defendant intentionally committed the act by sending explicit electronic information to the Blued application. Third is the violation of decency, represented by the defendant's act of sending photos of his genitals via the Blued application. Read within the context of this case, the lawscape of social media is measured and materialized by the abstract notion of a decent atmosphere. It no longer requires the other's seeing, desires, or even the common belief.

The idea of a decent atmosphere is considered a crucial category in anticipating public or social unrest, as shown in the Central Jakarta District Court Decision No. 572/Pid.Sus/2018/PN.JKT.PST. The defendants George and Henrie were the owners of the Gym Business, Health Steam Bath. Defendants Grace, Tommy, and Khanan were employees there. This business provides a pool, sauna, and cubicle where same-sex male couples can be freely naked and have sex with other men, even visitors can see the activities being carried out by same-sex couples. The Panel of Judges decided that the defendants were:

legally and convincingly proven guilty of committing a crime as charged by the Public Prosecutor, namely violating Article 30 Jo. Article 4 paragraph (2) of the Republic of Indonesia Law no. 44 of 2008 jo. Article 55 paragraph (1) of the lst Criminal Code, provides that: everyone [who] provides pornographic services as referred to in Article 4 paragraph (2): a. presenting explicit nudity or the appearance of nudity; b. explicitly presenting the genitals; c. exploitative or exhibiting sexual activity; or d. indirect sexual services, perform, order to do, or participate in doing

In its reasoning the Court considered that the defendants' actions had "violated the norms of decency and religious norms, which could disturb the community," and furthermore, "same-sex relationships are considered to be contrary to religious values and decency norms in society. LGBT acts are considered to cause unrest in society." 
Decent atmosphere, in this context, is thus to be understood as the supremacy of heteronormativity. Notwithstanding, any subversion of that normalcy could disrupt the entire atmosphere.

\section{THE LIFE, THE IDEOLOGICAL}

Living law, as understood in the examined passages of law, embeds the spatiotemporal and emotional dimensions of law, embodying what Valverde refers to as legal chronotope. ${ }^{46}$ Borrowing Bhaktin's literary theory, legal chronotope in socio-legal study considers 'time' and 'space' together, not as a separate dimensions of analysis. ${ }^{47}$ The daily (legal) experiences captured in the preceding sections are assemblages of various meanings and spaces tied up in ideologies. From this reading, there are three main characteristics of the dynamic relationship between law, emotion, and landscape - seeing, believing, and anticipating. They are rooted in the ideological dimension of law in Indonesia that recognizes (or, to be precise, imposes) Pancasila as "the source of all sources of law." For many Indonesians Pancasila as an ideology is considered the 'fruit of the crystallization of the nation's past, present, and future experiences.' This needs to be untangled into three interrelated and constitutive components of ideology, material, and law. To explain the relationship between these components, the following section draws upon Althusserian tradition of thinking about ideology "not only as false consciousness, but also [a form] of unconsciousness deeply embedded in the individual, which represent the product of material reality and social conditions fundamental in the community." 48

\section{A. Ideological Dimensions of Law}

Drawing on the Althusserian approach, Hunt does not consider ideology as a unitary entity, rather it "expresses its power in its ability to relate and combine diverse mental elements (concepts, ideas, etc.) and structure the perceptions and cognitions of social agents." 49 Such a view of ideology, he argues, "counsels us not to assume the coherence and consistency of legal discourse, but to search out the resonances of the social, economic, and political struggles that reside behind the smooth surface of legal reasoning and judicial utterance." 50 The ideological dimension of law must have a theoretical reflection, which is a metaphor for the correspondence between knowledge and reality. Terms later emerged that explain this connection: mirror, illusion, fantasy, facade, mystification, reification, or even distortion. Peter Gabel notes that we need to distinguish between: (a) the processes that create the ideological characteristics

\footnotetext{
${ }^{46}$ Mariana Valverde, Chronotopes of law: Jurisdiction, scale and governance (Oxon, New York: Routledge, 2015).

${ }^{47} \mathrm{Ibid}$ at 9-10.

${ }^{48}$ Justin Desautels-Stein \& Akbar Rasulov, "Deep Cuts: Four Critiques of Legal Ideology” (2021) 31:2 Yale

J Law Humanit 436-519; Louis Althusser, On the Reproduction of Capitalism: Ideology and Ideological State Apparatuses (London: Verso, 2014).

${ }^{49}$ Alan Hunt, "The Ideology of Law : Advances and Problems in Recent Applications of the Concept of Ideology to the Analysis of Law" (1985) 19:1 Law Soc Rev 11-37 at 16.

${ }^{50} \mathrm{Ibid}$.
} 
embedded in the law; and (b) those consequences flowing from law that have a particular ideological content. ${ }^{51}$ Consequently, the relationship between ideology and law, according to Hunt, can be explained in terms of three different levels: (a) the ideological content of concrete legal norms; (b) the ideological content of what are usually referred to as 'principles'; and (c) the ideological content of the 'legal form, ${ }^{52}$

At the heart of the effort to understand ideology is a question of "material determination." The first is concrete determination, which reveals that "the ideological content of law is largely manifest in the content of specific laws, whether judicial rules or specific legislative enactments. ${ }^{53}$ The second relates to form determination, which sees the ideological role of law in its concrete form. ${ }^{54}$ For this reason, ideological analyses of law must pay attention to three interrelated concepts, namely: ideological elements (the constituents of any text or speech act); ideological formations (complex systematizations of ideologies); and forms of ideological law (configurations of ideological elements where there has been conscious systematization). ${ }^{55}$ Through this, we are able to understand the complex structure of legal argumentation developed in the preceding section.

Article 2 of Law 12/2011 on the Drafting of Legislation stipulates that "Pancasila is the source of all sources of state law." It explains that:

[t] he placement of Pancasila as the source of all sources of state law is in accordance with the Preamble to the 1945 Constitution of the Republic of Indonesia in the fourth paragraph, namely Belief in One Supreme God, just and civilized humanity, Indonesian Unity, Democracy led by wisdom in Deliberation/Representation, and Social Justice for all Indonesian people. Placing Pancasila as the basis and ideology of the state as well as the philosophical basis of the state so that any material contained in the legislation may not conflict with the values contained in Pancasila.

Pancasila is thus the source of all legal sources, stated by Soekarno as philosofische grondslag or weltanschauung, and staatsfundamentalnorm in the legal system coined by Notonagoro. This was further affirmed by Utrecht who goes so far as to position Pancasila as the grundnorm within Kelsen's normative framework. This is interesting considering that Utrecht "recognizes Pancasila as ethics in the context of a state, while on the other hand Kelsen explicitly rejects the interpretation of such grundnorm as state ethics." ${ }^{26}$ The position of Pancasila in the Indonesian legal system cannot be separated from how legal

\footnotetext{
${ }^{51}$ Ibid at $21-22$.

52 Ibid at 22.

${ }^{53}$ Ibid.

${ }^{54}$ Ibid at 23.

${ }^{55} \mathrm{Ibid}$ at 33 .

${ }^{56}$ E Fernando M Manullang, "The Purpose of Law, Pancasila, and Legality According to Ernst Utrect: A Critical Reflection" (2015) 5:2 Indones Law Rev 187-207.
} 
scholars approach legal phenomena. Referring to Padmo Wahjono, Head of the Educational Development Agency for the Implementation of the Guidelines for Understanding and Practicing Pancasila (Badan Pembinaan Pendidikan Pelaksanaan Pedoman Penghayatan dan Pengamalan Pancasila), Manullang reveals that Pancasila is understood legally and formally, rather than as an abstract grundnorm or as a test for the validity of legal norms. ${ }^{57}$

This indicates how ideological analysis can be applied to law. From a foundationalist perspective, Manullang explained that:

it was not held for purely functional purposes; to stop the infinite validation system. There is an aspect of belief in it. In other words, there is a matter of intuition in it. It's not just a matter of logic. Thus, grundnorm - in the philosophical perspective of foundationalism - is a belief framework that is held to provide justification. Without belief, there can be no basis, regardless of whether or not a logical validation of norms should be carried out. ${ }^{58}$

According to him, Pancasila as a grundnorm is mythical,

[this] is because there is no reasonable reason that can answer; who decides something is grundnorm or not. This is because the existence of the grundnorm is a presupposition, which is considered to have existed from the beginning without being able to explain whether the grundnorm is a cause, or an effect. Anyway, it was assumed to exist suddenly. ${ }^{59}$

As a result, the efforts of Indonesian jurists to answer the question of whether the Pancasila grundnorm has been diluted "to the point that [Pancasila] is used as a mere normative validation reason." 60

Pancasila, as the basis for normative validation, has relatively diverse implications; it has the potential to facilitate or destroy democracy. ${ }^{61}$ In his study, Iskandar explains how Pancasila has become a fantasy whose implications in legal practice tends to facilitate restrictions that discriminate against minority groups. ${ }^{62}$ His review of the constitutional ruling on the Blasphemy Law reveals that Pancasila Democracy is "a collection of meaningless terms, used as new bottles into which the old wine of liberalism

\footnotetext{
${ }^{57} \mathrm{Ibid}$; E Fernando M Manullang, "Mempertanyakan Pancasila sebagai Grundnorm: Suatu Refleksi Kritis dalam Perspektif Fondasionalisme" (2020) 50:2 J Huk Pembang 284-301.

${ }^{58}$ Manullang, supra note 57 at 299.

${ }^{59}$ Ibid.

${ }^{60} \mathrm{Ibid}$ at 300.

${ }^{61}$ Michael Morfit, "Pancasila: The Indonesian State Ideology According to the New Order Government" (1981) 21:8 Asian Surv 838-851.

${ }^{62}$ Pranoto Iskandar, "The Pancasila Delusion" (2016) 46:4 J Contemp Asia 723-735.
} 
and communitarianism is poured. "63 Comments on the mystification of Pancasila are also found in the ritual to commemorate the Pancasila Sanctity Day, as an effort to preserve the authoritarian power. ${ }^{64}$ These findings necessitate an explanation of the performative effect of law, in particular how the myth of Pancasila as an ideology can be materialized, transforming the living law into an ideological dimension of atmosphere.

\section{B. Ideology, Materiality, and the Living Law}

Hunt believes that "[i]deology is perceived not as a form of consciousness, which is the conventional view, but as a constituent of the unconscious in which social relations are lived." ${ }^{65}$ In reviewing ideology and the state apparatus, Althusser expresses two main theses: (1) "ideology does not have 'an ideal, idea-dependent, or spiritual existence, but a material one', for 'an ideology always exists in an apparatus', and Ideological State Apparatuses are the site of a 'realization' of ideology;" and (2) "every ideology has the function (which defines it) of "constituting" [concrete individuals as] subjects." ${ }^{\text {" Based }}$ on the Gramscian metaphor of ideology as the 'cement' of society Poulantzas argues that, as Hunt quotes, "[i]deology, which slides into every level of the social structure, has the particular function of cohesion." 67

Ideology is not only about myth, which is divulged through the mechanization of signs and texts, but it is also material. ${ }^{68}$ As Davies notes,

ideology first of all concerns the way in which the relationship between the subject and the system is imagined, but secondly it is material - it is inscribed in material practices and rituals, performed by material subjects, and governed by material institutions. Subjects are interpellated as subjects of ideology and they transmit it through being inserted in a material sense into the practices of institutions. The imagining of the subject in the world is key, but so are the material practices that embed and reproduce the subject. ${ }^{69}$

Through this process of interpellation, we can see how Althusser's concept of materiality as practice relates to the nature of law that "occur[s] at a certain time and in a certain place, perceived by our senses."70 Materiality goes beyond "forms and consequences of productive relationships to include the human being performing rituals and following certain mandated practices - these materialities performed by subjects become the bridge between a system and its ideational form that allows it to reproduce itself." 71 This

\footnotetext{
${ }^{63}$ Ibid at 12.

${ }^{64}$ Katharine E McGregor, "Commemoration of 1 October, 'Hari Kesaktian Pancasila': a post mortem analysis?" (2002) 26:1 Asian Stud Rev 39-72.

${ }^{65}$ Hunt, supra note 49 at 16.

${ }^{66}$ Althusser, supra note 48 at xxvi.

${ }^{67}$ Hunt, supra note 49 at 17.

${ }^{68}$ Althusser, supra note 48; Abidin Kusno, After the new order: Space, politics, and Jakarta (University of Hawaii Press, 2013).

${ }^{69}$ Davies, supra note 16 at 53.

${ }^{70} \mathrm{Ibid}$ at 73.

${ }^{71}$ Ibid at 57.
} 
invites us to consider a discourse on new materialism which, in this case, focuses on "situating the human, including human meaning and human subjectivity, in a material world where all matter, living and non-living, is related, where objects have their own vitality and resistance, and where agency emerges in relation rather than as an existing quality." ${ }^{72}$ Understood this way, ideology is undoubtedly used as validation of (il)legal codes, as can be found in the legal reasoning of case law examined in the preceding chapter on decency-related crimes.

According to Margaret Davies the idea of legal performativity

... may take the form of an iteration of a pre-existing role, an interpretation perhaps of an abstract principle, and there is certainly a strong element of this in state law. Every time we follow a rule conveyed in text or speech, we are interpreting it for a material context. But performance is also in itself constitutive, and law is nothing more (or less) than the performances of a large number of social actors, often but not always mediated or consolidated by text. ${ }^{73}$ Seeing ideology in law is not only pertinent to its substance or content but also its rather performative effect. It cannot be denied that the materiality of Pancasila through law in Indonesia is a synthesis of elements to form an ideological 'legal form'. This materiality, in Karen Barad's logic of agency realism, is the product of an intra-agency discursive practice. ${ }^{74}$ Agents, either inside or outside the law, have an agency role in producing and transmitting Pancasila ideology into legal practice. Since law is practically everywhere, we may need to eliminate the distinction between legal and non-legal views because, it turns out, that all things can experience, quoting McGee, jurimorph - a process of material translation into legal discourse. ${ }^{75}$

This section has flowed from the ideological dimension of law to the legal dimension of daily life and its legal materiality. Pinpointed with the previous legal examination that unveils seeing, believing, and anticipating as forms of sensing the life in living law, ideology, based on Althusserian logic, infers a material consciousness that undergoes translation through and within the living law. This, in turn, shapes the individual, spaces, and atmosphere as a definite subject: the ideological. ${ }^{76}$

\section{CONCLUSION}

\footnotetext{
72 Ibid at 66

${ }^{73} \mathrm{Ibid}$ at $7 \mathrm{l}$.

${ }^{74}$ Karen Barad, "Posthumanist Performativity: Toward an Understanding of How Matter Comes to Matter" (2003) 28:3 Signs J Women Cult Soc 801-831.

${ }^{75}$ Kyle McGee, "On Devices and Logics of Legal Sense: Toward Socio-technical Legal Analysis" in Kyle McGee, ed, Latour Passage Law (Edinburgh: Edinburgh University Press, 2015) 61; Bruno Latour, "The Strange Entanglement of Jurimorphs" in Kyle McGee, ed, Latour Passage Law (Edinburgh: Edinburgh University Press, 2015) 331.

${ }^{76}$ Oleg Golubchikov, "The urbanization of transition: ideology and the urban experience" (2016) 57:4-5 Eurasian Geogr Econ 607-623; Kanishka Goonewardena, "The urban sensorium: Space, ideology and the aestheticization of politics" (2005) 37:1 Antipode 46-71.
} 
This article has expanded the socio-legal analysis of living law by scrutinizing the interplay between law, space, and emotion. It unravels the plurality of life within contemporary Indonesian society represented by the legal discourse of kesusilaan (decency). In this context, there has been a propensity that kesusilaan is part of the Indonesian living law that shapes and is shaped by emotional landscapes. Consequently, living law is materialized through sensing it. Based on the semantic findings, this article argues that sensing the living law is to be understood as seeing the physical legal landscape, believing the emotional common sense, and anticipation guided by communitarian atmosphere. This viewpoint destabilizes the concept of law, highlighting its non-linear state of being. Nonetheless, it is an important step for inquiring into spatial justice, specifically in the context of people living at the margins of society and in minority groups. Under this framework, the emancipatory and transformative character of law could only be achieved through "sustained critical-mass practices which bring new meanings, and new directions to legal culture." 77 The ideological dimension of Pancasila in the nation's legal system should materialize accordingly into these 'sustained critical-mass practices' - obliterating the ideology as a means of normative validation.

\section{ACKNOWLEDGEMENT}

None

\section{COMPETING INTEREST}

None

\section{REFERENCES}

Althusser, Louis, On the Reproduction of Capitalism: Ideology and Ideological State Apparatuses (London: Verso, 2014).

Banakar, Reza, Normativity in Legal Sociology: Methodological Reflections on Law and Regulation in Late Modernity (London: Springer, 2015).

Davies, Margaret, Law Unlimited: Materialism, Pluralism, and Legal Theory (New York: Routledge, 2017).

Deflem, Mathieu, Sociology of law: Visions of a scholarly tradition (Cambridge: Cambridge University Press, 2008).

Delaney, David, The Spatial, the Legal and the Pragmatics of World-Making: Nomospheric Investigation (New York: Routledge, 2010).

Ehrlich, Eugen, Fundamental Principles of the Sociology of Law (London, New York: Routledge, 2002).

Kusno, Abidin, After the new order: Space, politics, and Jakarta (University of Hawaii Press, 2013).

Olwig, Kenneth R, The meanings of landscape: Essays on place, space, environment and justice (Oxon, New York: Routledge, 2019).

Philippopoulos-Mihalopoulos, Andreas, Spatial Justice: Body, Lawscape, Atmosphere (New

\footnotetext{
${ }^{77}$ Margaret Davies, "The Law Becomes Us: Rediscovering Judgment” (2012) 20 Fem Leg Stud 167-181 at
} 178. 
York: Routledge, 2015).

Soesilo, R, Kitab Undang-Undang Hukum Pidana (KUHP) serta Komentar-Komentarnya Lengkap Pasal Demi Pasal (Bogor: Politeia, 2013).

Valverde, Mariana, Chronotopes of law: Jurisdiction, scale and governance (Oxon, New York: Routledge, 2015).

Azuela, Antonio \& Rodrigo Meneses-Reyes, "The everyday formation of the urban space: Law and poverty in Mexico City" in Irus Braverman et al, eds, Expand Spaces Law A Timely Leg Geogr (Stanford, CA: Stanford University Press, 2015) 167.

Bandes, Susan A \& Jeremy A Blumenthal, "Emotion and the law" (2012) 8:May Annu Rev Law Soc Sci 161-181.

Barad, Karen, "Posthumanist Performativity: Toward an Understanding of How Matter Comes to Matter" (2003) 28:3 Signs J Women Cult Soc 801-831.

Benda-Beckmann, Franz von \& Keebet von Benda-Beckmann, "Places that come and go: A legal anthropological perspective on the temporalities of space in plural legal orders" in Irus Braverman et al, eds, Expand Spaces Law A Timely Leg Geogr (Stanford, CA: Stanford University Press, 2014) 30.

_- _ " "The Social Life of Living Law in Indonesia" in Marc Hertogh, ed, Living Law Reconsidering Eugen Ehrlich (Oxford, Portland: Hart Publishing, 2009) 177.

Benda-Beckmann, Franz von, Keebet von Benda-Beckmann \& Anne Griffiths, "Space and legal pluralism: An introduction" in Franz von Benda-Beckmann, Keebet von Benda-Beckmann \& Anne Griffiths, eds, Spat law An Anthropol Geogr law Soc (Surrey: Ashgate, 2009) 1 .

Bennett, Luke \& Antonia Layard, "Legal Geography: Becoming Spatial Detectives" (2015) 9:7 Geogr Compass 406-422.

Braverman, Irus et al, "Expanding the Spaces of Law" in Expand Spaces Law A Timely Leg Geogr (Stanford, CA: Stanford University Press, 2014) 1.

Buana, Mirza Satria, "Living adat Law, Indigenous Peoples and the State Law: A Complex Map of Legal Pluralism in Indonesia" (2016) 1:3 Int J Indones Stud 104119.

Butler, Judith, "Performativity, precarity and sexual politics" (2009) 4:3 AIBR Rev Antropol Iberoam.

Conway, Heather \& John Stannard, "Contextualising Law and Emotion: Past Narratives and Future Directions" in Heather Conway \& John Stannard, eds, Emot Dyn Law Leg Discourse (Oxford and Portland, Oregon: Hart Publishing, 2016) 1.

Davies, Margaret, "The Law Becomes Us: Rediscovering Judgment" (2012) 20 Fem Leg Stud 167-181.

Delaney, David, "Legal geography I: Constitutivities, complexities, and contingencies" (2015) 39:1 Prog Hum Geogr 96-102.

_-_- "Seeing seeing seeing the legal landscape" in Nuala C Johnson, Richard H Schein \& Jamie Winders, eds, Wiley-Blackwell Companion to Cult Geogr (West Sussex: Wiley Blackwell, 2013) 238.

Desautels-Stein, Justin \& Akbar Rasulov, "Deep Cuts: Four Critiques of Legal Ideology" (2021) 31:2 Yale J Law Humanit 436-519.

Gendron, Maria, "The evolving neuroscience of emotion: challenges and opportunities for integration with the law" in Susan A Bandes et al, eds, Res Handb Law Emot (Cheltenham, UK; Northampton, USA: Edward Elgar Publishing, 2021) 27.

Golubchikov, Oleg, "The urbanization of transition: ideology and the urban experience" 
(2016) 57:4-5 Eurasian Geogr Econ 607-623.

Goonewardena, Kanishka, "The urban sensorium: Space, ideology and the aestheticization of politics" (2005) 37:1 Antipode 46-71.

Grossi, Renata, "Understanding law and emotion" (2015) 7:1 Emot Rev 55-60.

Haidt, Jonathan, "The emotional dog and its rational tail: a social intuitionist approach to moral judgment" (2001) 108:4 Psychol Rev 814.

Hexagraha, Shafira Anindia Alif, "Trajektori ko-produksi kota di Indonesia: Telaah geografi kritis" (2018) 5:1 J Huk Lingkung 88-116.

Hexagraha, Shafira Anindia Alif \& Savitri Nur Setyorini, “Tinjauan terhadap Konsep Keadilan Spasial dan Partisipasi Masyarakat dalam Perencanaan dan Pengendalian Pemanfaatan Ruang pada Program Normalisasi Ciliwung di Provinsi DKI Jakarta" (2019) 49:2 J Huk Pembang 349-375.

Hunt, Alan, "The Ideology of Law : Advances and Problems in Recent Applications of the Concept of Ideology to the Analysis of Law" (1985) 19:1 Law Soc Rev 11-37.

Iskandar, Pranoto, "The Pancasila Delusion" (2016) 46:4 J Contemp Asia 723-735.

Kahan, Dan M \& Martha C Nussbaum, "Two conceptions of emotion in criminal law" (1996) 96:2 Columbia Law Rev 269-374.

Latour, Bruno, "The Strange Entanglement of Jurimorphs" in Kyle McGee, ed, Latour Passage Law (Edinburgh: Edinburgh University Press, 2015) 331.

Lev, Daniel S, "Colonial Law and the Genesis of the Indonesian State" (1985) 40 Indonesia 57-74.

Manullang, E Fernando M, "Mempertanyakan Pancasila sebagai Grundnorm: Suatu Refleksi Kritis dalam Perspektif Fondasionalisme” (2020) 50:2 J Huk Pembang 284-301.

- - - "The Purpose of Law, Pancasila, and Legality According to Ernst Utrect: A Critical Reflection" (2015) 5:2 Indones Law Rev 187-207.

Maroney, Terry A, "Law and emotion: A proposed taxonomy of an emerging field" (2006) 30:2 Law Hum Behav 119-142.

- - - "Lay conceptions of emotion in law" in Susan A Bandes et al, eds, Res Handb law Emot (Cheltenham, UK; Northampton, USA: Edward Elgar Publishing, 2021) 15.

McGee, Kyle, "On Devices and Logics of Legal Sense: Toward Socio-technical Legal Analysis" in Kyle McGee, ed, Latour Passage Law (Edinburgh: Edinburgh University Press, 2015) 61.

McGregor, Katharine E, "Commemoration of 1 October, 'Hari Kesaktian Pancasila': a post mortem analysis?" (2002) 26:1 Asian Stud Rev 39-72.

Morfit, Michael, "Pancasila: The Indonesian State Ideology According to the New Order Government" (1981) 21:8 Asian Surv 838-851.

Nalle, Victor Imanuel, "Pendekatan Geografi Hukum Kritis dalam Kajian Hukum Tata Ruang Indonesia: Sebuah Wacana Filsafat Hukum dan Interdisiplin" (2021) 37:1 Justitia Pax J Huk 61-83.

Philippopoulos-Mihalopoulos, Andreas, "Atmospheres of law: Senses, affects, lawscapes” (2013) 7:1 Emot Sp Soc 35-44.

Rannila, Päivi \& Siiri Pyykkönen, "Public obscenity and the formation of emotional legal landscapes in Dries Verhoeven's Ceci n'est pas ...” (2020) 102:4 Geogr Ann Ser B, Hum Geogr 384-399.

Salampessy, M Yahdi, "Book Review The Leiden Legacy: Concepts of Law in Indonesia” (2014) 4:3 Indones Law Rev 385-388.

Umphrey, Martha M, "Law in Drag: Trials and Legal Performativity" (2012) 21:2 
Columbia J Gend Law 114-129.

Yulius, Hendri, "Double standards: The defining of homosexuality as pornographic in Indonesia", Jakarta Post (21 October 2016), online:

〈https://www.thejakartapost.com/academia/2016/10/21/double-standards-thedefining-of-homosexuality-as-pornographic-in-indonesia.html.>. 